medRxiv preprint doi: https://doi.org/10.1101/2022.02.07.22270557; this version posted February 8, 2022. The copyright holder for this preprint (which was not certified by peer review) is the author/funder, who has granted medRxiv a license to display the preprint in It is made available under a CC-BY-NC 4.0 International license .

\title{
History of SARS-CoV-2 infection, anti-spike IgG antibody kinetics and neutralization capacities following the second and third dose of BNT162b2 vaccine in nursing home residents
}

H. Jeulin ${ }^{\mathrm{a}, \mathrm{b}}$ PharmD, PhD, C. Labat ${ }^{\mathrm{c}}$ BsC , K. Duarte ${ }^{\mathrm{d}} \mathrm{PhD}, \mathrm{S}$. Toupance ${ }^{\mathrm{c},}$ PharmD, PhD, G. Nadin ${ }^{\mathrm{e}} \mathrm{PhD}$, D. Craus ${ }^{\mathrm{f}}$ MD, I. Georgiopoulos ${ }^{\mathrm{h}}$ MD, I. Gantois ${ }^{\mathrm{h}}$ MD, F. Goehringer ${ }^{\mathrm{g}} \mathrm{MD}$ and A. Benetos ${ }^{\text {ch }} * \mathrm{MD}, \mathrm{PhD}$ :

a Université de Lorraine, CNRS, LCPME, F-54000 Nancy, France

${ }^{\mathrm{b}}$ Laboratoire de Virologie, CHRU de Nancy Brabois, F-54500 Vandœuvre-lès-Nancy, France

${ }^{\mathrm{c}}$ Université de Lorraine, Inserm, DCAC, F-54500 Vandœuvre-lès-Nancy, France.

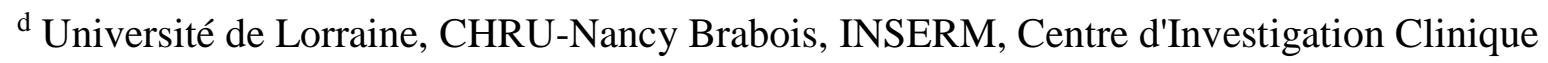
Pluridisciplinaire (CIC-P) 14-33, F-54500 Vandœuvre-lès-Nancy France

${ }^{\text {e }}$ Sorbonne Université, CNRS, LJLL, 75005 Paris, France

${ }^{\mathrm{f}}$ Maison Médicale F-54110 Rosières-aux-Salines, France

g Université de Lorraine, CHRU-Nancy Brabois, Service de maladies Infectieuses et tropicale F-54500 Vandœuvre-lès-Nancy France

${ }^{\mathrm{h}}$ Université de Lorraine, CHRU-Nancy Brabois, Department of Clinical Geriatrics F-54500 Vandœuvre-lès-Nancy France

Short title: post-vaccination $\operatorname{IgG}(\mathrm{S})$ in Nursing Home residents

*Address correspondence to:

Prof. Athanase Benetos, $\mathrm{MD}, \mathrm{PhD}$,

Head of the Department of Geriatrics, Hôpital Brabois,

Rue Morvan, 54500, Vandoeuvre-lès-Nancy,

University Hospital of Nancy (CHRU), Université de Lorraine, Nancy,

France. E-mail: a.benetos@chru-nancy.fr

This study has been supported by the PIA project "Lorraine Université d'Excellence" reference ANR-15-IDEX-04-LUE, and the FHU project CARTAGE-PROFILING (Aviesan, 2021-2025).

-The authors have declared no competing interest. 
medRxiv preprint doi: https://doi.org/10.1101/2022.02.07.22270557; this version posted February 8, 2022. The copyright holder for this preprint (which was not certified by peer review) is the author/funder, who has granted medRxiv a license to display the preprint in

It is made available under a CC-BY-NC 4.0 International license .

\begin{abstract}
Importance: Duration of post-vaccination protection against COVID-19 in individuals is a critical issue, especially in nursing home $(\mathrm{NH})$ residents, i.e. one of the most vulnerable populations.
\end{abstract}

Objective: To estimate the duration of the $\operatorname{IgG}(\mathrm{S})$ response to the mRNA BNT162b2 vaccine in $\mathrm{NH}$ residents with (COV-Yes) or without (COV-No) history of natural infection with SARS-CoV-2.

Design, setting and participants: $\operatorname{IgG}(\mathrm{S})$ quantification was carried out at 3 different time periods following administration of the Pfizer BioNtech vaccine: three then seven months after the $2^{\text {nd }}$ dose and one month after the $3^{\text {rd }}$ dose. 574 COV-Yes and COV-No NH residents were included in 2 cohorts: Main ( $n=115$, mean age 84 years) or Confirmatory ( $n=459$, mean age 88 years).

Exposure: All subjects received the BNT162b2 vaccine.

Main outcomes and measurements: $\operatorname{IgG}(\mathrm{S})$ antibodies and seroneutralization capacity.

Results: Neutralization capacity was strongly correlated with $\operatorname{IgG}(\mathrm{S})$ levels $\left(\mathrm{R}^{2}: 76 \%\right)$ without any difference between COV-Yes and COV-No groups for the same levels of $\operatorname{IgG}(\mathrm{S})$. COVYes, compared to the COV-No subjects showed 5-fold and 15-fold higher $\operatorname{IgG}(\mathrm{S})$ titers 3 and 7 months after the 2 nd dose, but less than 2-fold higher $\operatorname{IgG}(\mathrm{S})$ after the $3^{\text {rd }}$ dose, due to a more pronounced effect of the $3^{\text {rd }}$ dose in the COV-No group. These results were similar in both cohorts. After the $2^{\text {nd }}$ dose, duration of assumed robust protection $(\operatorname{IgG}(\mathrm{S})>264$ BAU/ml) was 2-fold higher in the COV-Yes vs. COV-No group: 12.60 (10.69-14.44) vs 5.76 (3.91-8.64) months, and this advantage was mainly due to the higher $\operatorname{IgG}(\mathrm{S})$ titers after the $2^{\text {nd }}$ dose and secondary to a slower decay over time. After the $3^{\text {rd }}$ dose, duration (months) of robust protection was estimated at 11.87 (9.88-14.87) (COV-Yes) and 8.95 (6.85-11.04) (COV-No).

Conclusions and relevance: In old subjects living in NH, history of SARS-CoV-2 infection provides a clear advantage in the magnitude and duration of high $\operatorname{IgG}(\mathrm{S})$ titers following the $2^{\text {nd }}$ dose. Importantly, the $3^{\text {rd }}$ dose induces a much more pronounced $\operatorname{IgG}(\mathrm{S})$ response than the $2^{\text {nd }}$ dose in COV-No subjects, the effect of which should be able to ensure in these subjects a prolonged protection against severe forms of COVID-19. 
medRxiv preprint doi: https://doi.org/10.1101/2022.02.07.22270557; this version posted February 8, 2022. The copyright holder for this preprint (which was not certified by peer review) is the author/funder, who has granted medRxiv a license to display the preprint in

It is made available under a CC-BY-NC 4.0 International license .

\section{Introduction}

Mass vaccination of nursing home $(\mathrm{NH})$ residents, the population most likely to develop severe forms of COVID-19, has resulted in an impressive decrease in SARS-CoV-2 contaminations as well as a dramatic decrease in COVID-19-related mortality (1). In France, NH residents received mRNA vaccines (mainly BNT162b2, Pfizer BioNtech) and the vast majority of them (81\%) were fully vaccinated between January and June 2021 (2), while the $3^{\text {rd }}$ dose was administered between October and December 2021. Clinical studies in NHs demonstrated that, after the second dose, this very old population was able to develop SARSCoV-2 IgG(S) antibodies, thus obtaining protection against severe forms of COVID-19 $(3,4)$, and that previous infection by SARS-CoV-2 increased the immunogenicity of the vaccines (4). This latter result has also been observed in younger adults (5-7).

One of the most critical issues is the duration of post-vaccination protection in individuals with or without history of natural SARS-CoV-2 infection (7-9). The waning in serum SARSCoV-2 antibodies has raised pressing questions regarding long-term immunity thus leading to the $3^{\text {rd }}$ dose vaccination.

In the present study, we investigated the $\operatorname{IgG}(\mathrm{S})$ response to the BNT162b2 vaccine in $\mathrm{NH}$ residents with or without history of SARS-CoV-2 infection at three different checkpoints: a) approximately three months after the leading 2 doses of the vaccine, b) four months later just before the booster $\left(3^{\text {rd }}\right)$ vaccine and $\left.c\right)$ one month after the booster vaccine. In addition, a sero-neutralization assay was performed for a subgroup of subjects and the results analyzed according their COVID-19 status and $\operatorname{IgG}(\mathrm{S})$ levels.

The results of these analyses should enable modelizing the decrease over time of $\operatorname{IgG}(\mathrm{S})$ SARS-CoV-2 antibodies and provide an estimate of the duration of protection of the $3^{\text {rd }}$ dose of the mRNA vaccine against severe forms of COVID-19 in this very old population.

\section{MATERIAL AND METHODS}

\section{Participants}

Two cohorts were formed (Main and Confirmatory) comprised of $\mathrm{NH}$ residents from the Nancy-Lorraine region with (COV-Yes) or without (COV-No) history of prior SARS-CoV-2 infection. Residents belonging in the Main cohort were included between April 17, 2021 and September 21, 2021 in 5 NHs, whereas subjects belonging in the Confirmatory cohort were included between August 10, 2021 and December 15, 2021 in 12 NHs (Supplemental Table 
medRxiv preprint doi: https://doi.org/10.1101/2022.02.07.22270557; this version posted February 8, 2022. The copyright holder for this preprint (which was not certified by peer review) is the author/funder, who has granted medRxiv a license to display the preprint in

It is made available under a CC-BY-NC 4.0 International license .

1). In the Main cohort, two $\operatorname{IgG}(\mathrm{S})$ quantifications were performed at mean 3 months $\left(1^{\text {st }}\right.$ $\operatorname{IgG}(\mathrm{S})$ quantification) and 7 months $\left(2^{\text {nd }} \operatorname{IgG}(\mathrm{S})\right.$ quantification) following the $2^{\text {nd }}$ vaccination, whereas in the Confirmatory cohort, a single $\operatorname{IgG}(\mathrm{S})$ quantification was performed 7 months after the $2^{\text {nd }}$ vaccination (also defined as $2^{\text {nd }} \operatorname{IgG}(\mathrm{S})$ quantification). In both cohorts, a $3^{\text {rd }}$ $\operatorname{IgG}(\mathrm{S})$ quantification was performed 1.5 months after the $3^{\text {rd }}$ (booster) dose (Figure 1). Age, sex, vaccination dates, SARS-CoV-2 infection dates, as well as $\operatorname{IgG}(\mathrm{S})$ quantification dates were recorded for all residents in both cohorts. In addition, for participants in the Main cohort, BMI, autonomy status and number of medications were also collected. This study was registered in ClinicalTrials.gov (NCT04964024) and received the approval of the Ethics Committee of the Nancy University Hospital (CHRU) (Comite d'Ethique CHRU de Nancy, decision $n^{\circ} 326$, August $3^{\text {rd }}, 2021$ ).

\section{Inclusion criteria for both cohorts}

(i) NH residents aged 65 and older, with or without prior SARS-CoV-2 infection. Previous infection was identified either by history of positive RT-PCR or by anti-nucleoprotein $(\mathrm{N})$ IgG quantification.

(ii) SARS-CoV-2 anti-spike $\operatorname{IgG}(\mathrm{S})$ antibody quantification performed using the same quantification method (10) in the same laboratory.

(iii) Complete vaccination scheme, meaning two injections of the BNT162b2 mRNA vaccine with the second injection at least 12 days before the first antibody quantification.

(iv) Consent of the NH residents or their tutors for the use of the clinical and biological results for the aims of this study.

\section{Method for IgG(S) quantification}

Blood samples were centrifuged to collect serum, the latter of which was stored at $-20^{\circ} \mathrm{C}$. Antispike IgGs were detected using the LIAISON® SARS-CoV-2 TrimericS IgG assay (Diasorin SA, France) on a Liaison XL Device (Diasorin SA, France), based on recombinant Trimeric Spike glycoprotein as capture antigen (10). Quantitative results are expressed as Binding Antibody Units (BAU/mL) according to the WHO first International Standard (IS) for antiSARS-CoV-2 immunoglobulin (NIBSC code 20/136). Positive threshold was $\geq 33.8 \mathrm{BAU} / \mathrm{mL}$. Samples with antibody titer $>2080$ were diluted to $1: 20$ as recommended by the manufacturer in order to determine accurate IgG levels. For technical reasons the samples of 14 patients of 
medRxiv preprint doi: https://doi.org/10.1101/2022.02.07.22270557; this version posted February 8, 2022. The copyright holder for this preprint (which was not certified by peer review) is the author/funder, who has granted medRxiv a license to display the preprint in

It is made available under a CC-BY-NC 4.0 International license .

the Main and 6 patients from the Confirmatory cohort were not further diluted and these subjects were considered to have the plateau value of $2080 \mathrm{BAU} / \mathrm{ml}$.

\section{Microneutralization assay}

A sub-population of $39 \mathrm{NH}$ residents was selected from the entire population according to $\operatorname{IgG}(\mathrm{S})$ levels following the $2^{\text {nd }}$ vaccination ("low" $<650 \mathrm{BAU} / \mathrm{ml}$ vs. "high" $>2080 \mathrm{BAU} / \mathrm{ml}$ ) and prior SARS-CoV-2 infection (COV-Yes vs. COV-No) to assess serum neutralization capacities. Thus, 4 groups were studied: COV-No/low $\operatorname{IgG}(\mathrm{S}), \mathrm{n}=10$, median 215 BAU/ml; COV-Yes/low IgG(S), n=10, median 217 BAU/ml; COV-No/high IgG, n=9, median 3270 BAU/ml; and COV-Yes/high IgG, n=10, median 4486 BAU/ml.

The SARS-CoV-2 B.1.617.2 (Delta) strain from a positive respiratory sample (Covi-Lor collection, Nancy University Hospital, France) was cultured on Vero E6 cells. Sera positive for anti-SARS-CoV-2 antibodies were diluted from $1 / 10$ to $1 / 640$ and incubated with live-virus suspension for $2 \mathrm{hr}$. Cells were inoculated with the final suspension. Each dilution was tested five times in each experiment and each sample was tested in two independent experiments. The cytopathic effect was read on day +6 .

Negative controls consisted of uninfected cells while positive controls consisted of the virus incubated without sera and virus incubated with SARS-CoV-2-negative sera at a 1/10 ratio. The samples were classified according to neutralization activity at the 1:40 dilution, i.e. neutralization $>50 \%($ NT50).

\section{Statistical analyses}

Descriptive IgG data are presented as medians (IQR) and as mean (SD) values or percentages for the other variables. Due to the absence of normal distribution of $\operatorname{IgG}(\mathrm{S})$ values, comparisons between the different groups were performed after logarithmic transformation. Comparisons were conducted with ANOVA tests. Age and time $(\Delta)$ between the last immune stimulation (COVID-19 or vaccine) and antibody quantification were used for the adjusted models. Multiple regression analyses were also performed to test the role of clinical and demographic variables, time from immunization, and history of prior SARS-CoV-2 infection on $\operatorname{IgG}(\mathrm{S})$ levels. Pearson's correlation was used to study the association between $\operatorname{IgG}(\mathrm{S})$ values and time of immunization for each studied group (see Figure 2). P <0.05 was considered statistically significant.

In an additional analysis NH residents were classified into 4 categories according to $\operatorname{IgG}(\mathrm{S})$ level in BAU/ml: $\geq 34$ (level of positivity), $\geq 264$ (threshold associated with higher protection 
medRxiv preprint doi: https://doi.org/10.1101/2022.02.07.22270557; this version posted February 8, 2022. The copyright holder for this preprint (which was not certified by peer review) is the author/funder, who has granted medRxiv a license to display the preprint in

It is made available under a CC-BY-NC 4.0 International license .

against severe COVID-19 forms (11), $\geq 2080$ threshold highly predictive of strong neutralization response (12) Differences between COV-No vs. COV-Yes were compared using a $\chi^{2}$ test.

Models used for the assessment of IgG decay with time: In both cohorts, the natural logarithm of the $\mathrm{IgG}$ rate follows a linear regression with steepness $\mathrm{B}(1)$, meaning that the decay rate of the $\mathrm{IgG}$ is exponential. Hence, the proportion $\mathrm{q}_{30}$ of $\mathrm{IgG}$ that is lost during one month is $\mathrm{q}_{30}=$ $1-\exp (30 * \mathrm{~B}(1))$.

If the rate of $\operatorname{IgG}(\mathrm{S})$ decays exponentially by a proportion $\mathrm{q}_{30}$ each month, then if a quantity $\mathrm{I}(0)$ is measured at time $\mathrm{t}=0$, the immunity will be lost at a time $\mathrm{t}_{\text {loss }}$ (in months) at which the $\operatorname{IgG}(\mathrm{S})$ rate equals $\mathrm{I}_{\text {loss }}$ given by $\mathrm{t}_{\operatorname{loss}}=-\log \left(\mathrm{I}(0) / \mathrm{I}_{\text {loss }}\right) / \log \left(1-\mathrm{q}_{30}\right)$.

A linear mixed model with random effect on subjects was used to examine IgG kinetics after the second dose of vaccine in the Main cohort. The dependent variable consisted of the $\operatorname{IgG}(\mathrm{S})$ level, which was log-transformed. Fixed effect covariates included time after the second dose of vaccine in months as linear, SARS-CoV-2 status, and interaction between time and SARS-CoV-2 status. Given the low power of interaction tests $(13,14)$, a significance level of 0.10 was used for interaction p-values. Similar analysis was performed in the Confirmatory cohort using a classical linear regression model.

\section{RESULTS}

\section{Cohort characteristics}

The Main cohort was comprised of 115 subjects (41 COV-No and 75 COV-Yes) whereas the Confirmatory cohort was comprised of 459 subjects (366 COV-NO and $93 \mathrm{COV}$-Yes) (Figure 2). Demographic characteristics and $\operatorname{IgG}(\mathrm{S})$ levels are presented in Table 1. BMI, autonomy status and number of daily medications collected in the Main cohort were similar in the COVYes and COV-No groups.

\section{SARS-CoV-2 IgG(S) antibody quantification: comparison between COV-No vs. COV-Yes} groups

In the Main cohort (Table 1, left), significantly lower $\operatorname{IgG}(\mathrm{S})$ titers were found in the COV-No vs. COV-Yes subjects for $1^{\text {st }} \operatorname{IgG}(\mathrm{S})$ quantification (median: 621 vs. $2901 \mathrm{BAU} / \mathrm{ml}$ )) ( $\mathrm{p}<0.001)$. No difference in $\operatorname{IgG}(\mathrm{S})$ (time-adjusted) levels were observed between the subjects who presented SARS-CoV-2 infection before or after the $2^{\text {nd }}$ vaccination (Table 1 legend). The same results were observed for the $2^{\text {nd }} \operatorname{IgG}$ quantification for both cohorts (Table 1, right). After the booster dose ( $3^{\text {rd }} \operatorname{IgG}$ quantification), $\operatorname{IgG}(\mathrm{S})$ increased dramatically in all 
medRxiv preprint doi: https://doi.org/10.1101/2022.02.07.22270557; this version posted February 8, 2022. The copyright holder for this preprint (which was not certified by peer review) is the author/funder, who has granted medRxiv a license to display the preprint in

It is made available under a CC-BY-NC 4.0 International license .

groups. A significant difference in favor of COV-Yes was found only in the Confirmatory cohort (3795 vs. $6675 \mathrm{BAU} / \mathrm{ml})(\mathrm{p}<0.01)$. No differences in $\mathrm{IgG}(\mathrm{S})$ levels were observed between the Main and Confirmatory cohorts in each COVID-19 status group both for the $2^{\text {nd }}$ and $3^{\text {rd }} \mathrm{IgG}$ quantifications. The COV-Yes/COV-No $\operatorname{IgG}(\mathrm{S})$ ratio after the $3^{\text {rd }}$ dose dramatically decreased compared to the ratio after the $2^{\text {nd }}$ dose ( $2^{\text {nd }}$ quantification $)$ from 16.9 to 1.6 (Main cohort) and from 15.3 to 1.8 (Confirmatory cohort).

The evolution of the individual $\operatorname{IgG}(\mathrm{S})$ levels in the two groups of the Main cohort in residents having all $3 \mathrm{IgG}(\mathrm{S})$ measurements showed that, in the COV-No group, the response to the $3^{\text {rd }}$ vaccination was significantly higher than the response to the $2^{\text {nd }}$ vaccination, whereas no such difference was observed in the COV-Yes group (Supplemental Figure 2). Figure 3 shows the classification of residents according to $\operatorname{IgG}(\mathrm{S})$ levels during the different quantifications: $95.1 \%$ of the COV-No and $100 \%$ of the COV-Yes residents of the Main cohort (upper panel) showed a positive SARS-CoV-2 (>34 BAU/ml) serology during the first $\mathrm{IgG}(\mathrm{S})$ quantification. A more pronounced $\mathrm{IgG}(\mathrm{S})$ response in the COV-Yes was clearly observed during the first and the second quantifications $(p<0.0001)$ but not in the $3^{\text {rd }}$ especially in the Confirmatory cohort $(\mathrm{p}=0.47)$. Noteworthy, in the $2^{\text {nd }}$ quantification performed 7 months after the second dose, the percentage of residents with levels $>264$ $\mathrm{BAU} / \mathrm{ml}$, reached up to $93 \%$ in the COV-Yes group but only $28 \%$ in the COV-No groups of the Main and $92.5 \%$ and $28,2 \%$ in the Confirmatory cohort respectively.

Multivariate analyses in the Main cohort revealed that $\operatorname{IgG}(\mathrm{S})$ levels during the first and the second quantifications were dependent on both SarS-CoV-2 status $(\mathrm{p}<0.00001)$ and time since last immunization $(\mathrm{p}<0.001)$. Age, sex and clinical parameters did not influence $\operatorname{IgG}(\mathrm{S})$ levels,.

\section{Microneutralization assay}

A strong positive relationship was found between $\operatorname{IgG}(\mathrm{S})$ levels and neutralization activity (NT50) $(\mathrm{R} 2=0.77, \mathrm{p}<0.001)$ (Supplemental Figure 1). No difference was observed when comparing neutralization activity of post-vaccination serum in residents with or without history of prior COVID-19 (COV-Yes vs. COV-No: $\mathrm{p}=0.102$ for low $\operatorname{IgG}(\mathrm{S})$ titers and $\mathrm{p}=0.567$ for high IgG titers. Multivariate analysis, showed that neutralization activity was determined by $\operatorname{IgG}(\mathrm{S})$ levels $(\mathrm{p}<0.0001)$ but not by SARS-CoV-2 status $(\mathrm{p}=0.98)$. 
medRxiv preprint doi: https://doi.org/10.1101/2022.02.07.22270557; this version posted February 8, 2022. The copyright holder for this preprint (which was not certified by peer review) is the author/funder, who has granted medRxiv a license to display the preprint in

It is made available under a CC-BY-NC 4.0 International license .

Serum from NH residents with low-level IgG titers $(<264 \mathrm{BAU} / \mathrm{mL})$ neutralized the virus in vitro (NT50 $\geq 40)$ in 2/17 (11.8\%) cases, whereas serum from $\mathrm{NH}$ residents with high-level IgG titers $(\geq 264 \mathrm{BAU} / \mathrm{mL})$ neutralized the virus in vitro $(\mathrm{NT} 50 \geq 40)$ in all $22 / 22(100 \%)$ cases ( $\mathrm{p}<0.0001$ vs. low IgG titers).

\section{IgG waning rates in the Main and the Confirmatory cohorts}

IgG decay over time followed an exponential pattern, which allowed establishing a linear model between the $\log$ of $\operatorname{IgG}$ and the time since the $2^{\text {nd }}$ vaccination (Table 2). In the Main cohort, the beta coefficients of the IgG/time relationship were highly significant for both groups $(\mathrm{p}<0.001)$ and the interaction between time and SARS-CoV-2 status group was significant ( $\mathrm{p}=0.051$ ). The proportion of $\operatorname{IgG}(\mathrm{S})$ lost during one month, estimated from the linear mixed model, was $29.5 \%$ (95\% CI: 26.4-32.5) in the COV-No group and $25.4 \%$ (95\% CI: 22.6-28.0) in the COV-Yes group. Figure 4 shows the distribution of $\operatorname{IgG}(\mathrm{S})$ levels according to time after the second dose and SARS-CoV-2 status in the Main and the Confirmatory cohorts.

\section{Estimation of immunization duration and robust protection following the $3^{\text {rd }}$ dose}

For this estimation, the results of the $\operatorname{IgG}(\mathrm{S})$ decay in the Main (longitudinal) cohort were used with the assumption that the waning rates of $\operatorname{IgG}(\mathrm{S})$ over time in each COVID-19 status group were similar after the $3^{\text {rd }}$ dose as compared to the observed decay after the $2^{\text {nd }}$ dose. Following this analysis in the totality of the subjects who had received the $3^{\text {rd }}$ dose $(n=389)$, the time (months) to return, under the threshold of $264 \mathrm{BAU} / \mathrm{ml}$ in the COVID-No group was estimated at 8.95 (6.85-11.04) (median (IQR)) after the 3rd dose vs. 5.76 (3.91-8.64) $(\mathrm{p}<0.00001)$ after the $2^{\text {nd }}$ dose and $11.87(9.88-14.87)$ vs. $12.60(10.69-14.44)(\mathrm{NS})$ in the COV-Yes group, respectively.

The corresponding times to return under the positivity levels ( $<35 \mathrm{BAU} / \mathrm{ml})$ in COVID-No residents were estimated at $14.73(12.63-16.83)$ vs. 11.54 (9.69-14.42) months $(\mathrm{p}<0.00001)$ and 18.77 (16.78-21.76) vs. 19.50 (17.58 - 21.34) months (NS) in the COVID-Yes residents, respectively.

For both the $2^{\text {nd }}$ and 3rd doses, these times were longer in the COV-Yes than the COV-No group ( $<<0.0001)$, while the difference in absolute values related to COVID status were also attenuated after the $3 \mathrm{rd}$ dose. 
medRxiv preprint doi: https://doi.org/10.1101/2022.02.07.22270557; this version posted February 8, 2022. The copyright holder for this preprint (which was not certified by peer review) is the author/funder, who has granted medRxiv a license to display the preprint in

It is made available under a CC-BY-NC 4.0 International license .

\section{Discussion}

In the present study, we analyzed the $\operatorname{IgG}(\mathrm{S})$ response to the $2^{\text {nd }}$ and $3^{\text {rd }}$ doses of the Pfizer BioNtech mRNA vaccine in 2 different cohorts (Main and Confirmatory) comprised of a total of $574 \mathrm{NH}$ residents. This design enabled us to show that the totality of the results observed in the Main Cohort were also observed in the Confirmatory cohort which, in our opinion, provides robustness to the data and conclusions presented herein.

The study's focus was aimed at assessing the $\operatorname{IgG}(\mathrm{S})$ response after the $2^{\text {nd }}$ and the $3^{\text {rd }}$ vaccination since there is currently sufficient evidence regarding the importance of $\operatorname{IgG}(\mathrm{S})$ titers for the robust protection against severe forms of the disease, which is a major concern in this very old and highly frail population. In addition, in a subgroup of this population, we analyzed the relationship between $\operatorname{IgG}(S)$ and neutralizing capacity in residents with or without prior SARS-CoV-2 infection.

Two methodological aspects of the present study are particularly noteworthy:

-The method used for antibody quantification involved a whole recombinant trimeric protein for the detection of $\operatorname{IgG}(10)$. This method therefore allows detecting all antibodies directed against the $\mathrm{S}$ protein, and not only those linked to the RBD, the ACE2 binding site. The quantification range of this method is linked to the WHO standard, thus allow determining the $\operatorname{IgG}(\mathrm{S})$ titer in $\mathrm{BAU} / \mathrm{mL}(15)$.

-Similarly, the conventional microneutralization method used herein was based on the original live SARS-CoV-2 virus to better approximate in vivo humoral immunity.

Due to their characteristics, the results of these two methods are expected to be correlated and allow a relevant approach to the correlate of protection of anti-SARS-CoV-2 $\operatorname{IgG}(\mathrm{S})$. Thus, as shown in previous reports $(3,8)$ the neutralization capacity was strongly correlated with $\mathrm{IgG}(\mathrm{S})$ levels in both COV-Yes and COV-No subjects. Of particular interest is that for similar levels of $\operatorname{IgG}(\mathrm{S})$, no difference between COV-No vs. COV-Yes was observed.

A number of clinical studies conducted in $\mathrm{NH}$ have shown that residents with a history of SARS-Cov-2 infection showed a more pronounced post-vaccination $\operatorname{IgG}(\mathrm{S})$ level than residents without prior infection $(3,4)$. Our study confirms this significant difference and further adds key information showing that 7 months after the $2^{\text {nd }}$ dose, this difference was even more pronounced, i.e. the COV-Yes group showed median $\operatorname{IgG}(\mathrm{S})$ titers 15 -fold higher than the COV-No group, in both the Main and Confirmatory cohorts. In addition, the percentage of subjects with $\operatorname{IgG}(\mathrm{S})$ titers $>264 \mathrm{BAU} / \mathrm{ml}$, was only $28 \%$ in COV-No residents of the both cohorts, whereas among COV-Yes residents, approximately $93 \%$ in both cohorts 
medRxiv preprint doi: https://doi.org/10.1101/2022.02.07.22270557; this version posted February 8, 2022. The copyright holder for this preprint (which was not certified by peer review) is the author/funder, who has granted medRxiv a license to display the preprint in It is made available under a CC-BY-NC 4.0 International license .

featured $\mathrm{IgG}(\mathrm{S})$ titers $>264 \mathrm{BAU} / \mathrm{ml}$ which seems associated to robust protection (11). These results indicate that among $\mathrm{NH}$ residents, the risk of loss of immunity over a relatively short period following the initial 2-dose vaccination is much higher in subjects without prior SARSCoV-2 infection.

As also shown previously (16), our analyses revealed that in both COVID status groups, the decay in $\operatorname{IgG}(\mathrm{S})$ followed an exponential pattern, which allowed obtaining a linear relationship between the $\log -\operatorname{IgG}(\mathrm{S})$ and time interval after the second vaccination. These analyses showed that COV-Yes residents presented a duration of immunization more than twice that of COV-No residents, primarily due to the much higher $\operatorname{IgG}(\mathrm{S})$ levels after the second vaccination in the COV-Yes group and secondarily due to the lower rates of $\operatorname{IgG}(\mathrm{S})$ waning in COV-Yes individuals.

Of note, following the $3^{\text {rd }}$ vaccination, the $\operatorname{IgG}(\mathrm{S})$ levels were higher than those observed after the $2^{\text {nd }}$ dose in COV-No residents, thereby leading to an approximate $50 \%$ increase in the duration of robust protection in this group after the $3^{\text {rd }}$ vaccination, although this effect was still less pronounced than the duration of robust protection of the $3^{\text {rd }}$ dose in the COV-Yes group. These results suggest that in NH residents without prior history of SARS-CoV-2 infection, protection against the severe forms of COVID-19 with the 3rd dose will be considerably longer compared to the $2^{\text {nd }}$ dose and similar to the protection obtained in COVYes subjects after the 2nd vaccination.

This study has two main limitations: first, the definition of COV-Yes by PCR and/or IgG(N)+ cannot eliminate that some subjects considered as being COV-No, had indeed a history of previous asymptomatic SARS-Cov-2 infection (7). Second, only exploration of humoral but not cellular immunity was performed, which probably has an important role in the prevention of serious disease forms. Moreover, the emergence of omicron or other variants in the future may modify the duration of protection.

In conclusion, in this very old population of NH residents, previous SARS-Cov-2 infection induces a more pronounced $\operatorname{IgG}(\mathrm{S})$ response to the BNT162b2 vaccine leading to a longer protection of the 2 nd dose and in a lesser degree of the $3^{\text {rd }}$ dose. We anticipate than in NH residents without history of SARS-CoV-2, the $3^{\text {rd }}$ dose of the RNA vaccine, compared to the $2^{\text {nd }}$ dose, will induce a more prolonged protection against severe forms of COVID-19. 
medRxiv preprint doi: https://doi.org/10.1101/2022.02.07.22270557; this version posted February 8, 2022. The copyright holder for this preprint (which was not certified by peer review) is the author/funder, who has granted medRxiv a license to display the preprint in

\section{References}

1. Teran RA, Walblay KA, Shane EL, Xydis S, Gretsch S, Gagner A et al. Postvaccination SARS-CoV-2 infections among skilled nursing facility residents and staff members - Chicago, Illinois, December 2020-March 2021. MMWR Morb Mortal Wkly Rep. 2021;30;70:632638 .

\section{2. https://www.santepubliquefrance.fr/content/download/354025/3069653}

3. Helle F, Moyet J, Demey B, François C, Duverlie G, Castelain S et al. Humoral antiSARS-CoV-2 immune response after two doses of Comirnaty vaccine in nursing home residents by previous infection status. Vaccine. 2022;40:531-535.

4. Salmerón Ríos S, Cortés Zamora EB, Avendaño Céspedes A, Romero Rizos L, SánchezJurado PM, Sánchez-Nievas G et al. Immunogenicity of the BNT162b2 vaccine in frail or disabled nursing home residents: COVID-A study. J Am Geriatr Soc. 2021;69:1441-1447.

5. Gaebler C, Wang Z, Lorenzi JCC, Muecksch F, Finkin S, Tokuyama M et al. Evolution of antibody immunity to SARS-CoV-2. Nature. 2021;591:639-644.

6. Stamatatos L, Czartoski J, Wan YH, Homad LJ, Rubin V, Glantz H et al. mRNA vaccination boosts cross-variant neutralizing antibodies elicited by SARS-CoV- 2 infection. Science 2021;372:1413-1418.

7. Gallais F, Gantner P, Bruel T, Velay A, Planas D, Wendling MJ et al. Evolution of antibody responses up to 13 months after SARS-CoV-2 infection and risk of reinfection. EBioMedicine 2021 Sep;71:103561. doi: 10.1016/j.ebiom.2021.103561.

8. Levin EG, Lustig Y, Cohen C, Fluss R, Indenbaum V, Amit S et al. Waning Immune Humoral Responseto BNT162b2 Covid-19 Vaccine over six Months. N Engl J Med. 2021; 385:e84. DOI: 10.1056/NEJMoa2114583.

9. Zhong D, Xiao S, Debes AK, Egbert ER, Caturegli P, Colantuoni E et al. Durability of Antibody Levels After Vaccination With mRNA SARS-CoV-2 Vaccine in Individuals With or Without Prior Infection. JAMA 2021;326:2524-2526.

10. Bonelli F, Blocki FA, Bunnell T, Chu E, De La O A, Grenache DG al. Evaluation of the automated LIAISON® SARS-CoV-2 TrimericS IgG assay for the detection of circulating antibodies. Clin Chem Lab Med 2021;59:1463-1467.

11. Feng S, Phillips DJ, White T, Sayal H, Aley PK, Bibi S et al. Correlates of protection 
medRxiv preprint doi: https://doi.org/10.1101/2022.02.07.22270557; this version posted February $8,2022$. The copyright holder for this preprint (which was not certified by peer review) is the author/funder, who has granted medRxiv a license to display the preprint in

It is made available under a CC-BY-NC 4.0 International license .

against symptomatic and asymptomatic SARS-CoV-2 infection. Nat Med. 2021;27:20322040.

12. Meschi S, Matusali G, Colavita F, Lapa D, Bordi L, Puro Vet al. Predicting the protective humoral response to a SARS-CoV-2 mRNA vaccine. Clin Chem Lab Med. 2021;59:2010 2018.

13. Greenland S. Tests for interaction in epidemiologic studies: a review and a study of power. Stat Med. 1983;2:243-251.

14. Brookes ST, Whitely E, Egger M, Smith GD, Mulheran PA, Peters TJ. Sub-group analyses in randomized trials: risks of subgroup-specific analyses; power and sample size for the interaction test. J Clin Epidemiol. 2004;57:229-236.

15. Scheiblauer H, Nübling CM, Wolf T, Khodamoradi Y, Bellinghausen C, Sonntagbauer M. et al. Antibody response to SARS-CoV-2 for more than one year kinetics and persistence of detection are predominantly determined by avidity progression and test design. J Clin Virology. 2022;146:105052.

16. Khoury DS, Cromer D, Reynaldi A, Schlub TE, Wheatley AK et al. Neutralizing antibody levels are highly predictive of immune protection from symptomatic SARS-CoV-2 infection. Nat Med. 2021;27:1205-1211.

\section{Acknowledgments}

Tha authors thank the following medical coordinators of the participating NHs :Marc Berr, Thierry Collin, Caroline Ferry-Bert, Marie-Chrisine Godard, Patrick Lucquin, Lydie Osnowycz, Henri Rozenfarb;

We thank Ms Anne Fréminet, Alice Metz and Cecile Lacomy for their valuable contribution. We thank all the directors and the staff of the 14 nursing homes for contributing to the realization of this study. We thank Mr Pierre Pothier for language review and stimulating discussions. 
Table 1: Clinical data and IgG(S) levels in the Main and Confirmatory cohorts in the two subgroups of NH residents with (COV-Yes) or without (COV-No) history of prior SARS-CoV-2 infection

\begin{tabular}{|c|c|c|c|c|c|c|c|c|}
\hline & \multicolumn{3}{|c|}{ Main cohort } & \multicolumn{5}{|c|}{ Confirmation cohort } \\
\hline & COV-No & $\mathrm{N}$ & COV-Yes & $\mathrm{N}$ & $\mathrm{COV}-\mathrm{No}$ & $\mathrm{N}$ & COV-Yes & $\mathrm{N}$ \\
\hline Women (\%) & $63 \%$ & 41 & $73 \%$ & 74 & $78 \%$ & 366 & $73 \%$ & 93 \\
\hline Age (years) & $84 \pm 9$ & 41 & $84 \pm 10$ & 74 & $88 \pm 8$ & 366 & $87 \pm 8$ & 93 \\
\hline BMI & $25.0 \pm 7.0$ & 40 & $25.6 \pm 5.2$ & 68 & - & & - & \\
\hline GIR & $1.90 \pm 0.63$ & 40 & $1.90 \pm 0.92$ & 68 & - & & - & \\
\hline Number of treatments & $6.93 \pm 2.56$ & 40 & $7.38 \pm 3.49$ & 68 & - & & - & \\
\hline 1st IgG (S) (BAU/ml) & $621(189-1741)$ & 41 & $2901(1873-7805) * * * \$$ & 74 & & & & \\
\hline 2nd IgG (S) (BAU/ml) & $92(46-415)$ & 41 & $1555(776-2080) * * *$ & 74 & $114(38-322)$ & 366 & $1740(1095-2900) * * *$ & 93 \\
\hline 3rd $\operatorname{IgG}(\mathrm{S})(\mathrm{BAU} / \mathrm{ml})$ & $3040(1880-7970)$ & 35 & 4965 (3070-9393) (NS) & 48 & $3795(1748-7470)$ & 254 & $6675(2503-14550) * *$ & 52 \\
\hline D Time 1 st IgG (S) (days) \# & $84 \pm 22$ & 41 & $101 \pm 68$ & 74 & & & & \\
\hline D Time 2nd IgG (S) (days) \# & $210 \pm 31$ & 41 & $215 \pm 38$ & 74 & $212 \pm 38$ & 366 & $173 \pm 41 * * *$ & 93 \\
\hline D Time 3rd IgG (S) (days) \#\# & $44 \pm 8$ & 35 & $42 \pm 10$ & 48 & $39 \pm 10$ & 254 & $42 \pm 13$ & 52 \\
\hline
\end{tabular}

$\mathrm{IgG}(\mathrm{S})(\mathrm{BAU} / \mathrm{ml})$ represent median (IQR) values. BMI, body mass index, GIR, Group Iso Ressources: Dependence score of dependence from 1 (completely dependent for most daily life activities to 6 (completely independent) by using the AGGIR grid (Autonomy, Gerontology Group Iso Resources). Assessment of this score is mandatory for all NH resident in France (https://www.capretraite.fr/aide-a-domicile/pertedautonomie/grille-aggir/).

\# Delta time between $2^{\text {nd }}$ vaccination or COVID-19 (if occurred after the $2^{\text {nd }}$ vaccination) and the $1^{\text {st }}$ or $2^{\text {nd }} \operatorname{IgG}(\mathrm{S})$ quantification. \#\# Delta time between $3^{\text {rd }}$ vaccination and $3^{\text {nd }} \operatorname{IgG}(\mathrm{S})$ quantification. $* * \mathrm{p}<0.01$ and $* * * \mathrm{p}<0.001 \mathrm{vs.} \mathrm{COV-No}$ of the same cohort. \$ Among the $74 \mathrm{COV}-$ Yes subjects, 50 had SARS-Cov-2 infection before the first vaccination and 20 a few days after the $2^{\text {nd }}$ dose. After adjusting for the time since the last immunization, the $1^{\text {st }} \operatorname{IgG}(\mathrm{S})$ quantification showed similar levels in these 2 subgroups (median (IQR)): 3133 (1896-7497 vs. 2791 (1483-7592) respectively $(\mathrm{p}=0.54)$. 
Tableau 2: Linear regression models for the association with $\log -\operatorname{IgG}(\mathrm{S})$ after the second dose of BNT162b2 vaccine

\begin{tabular}{|l|l|l|l|l|}
\hline & $\begin{array}{l}\text { Main cohort } \\
\text { (linear mixed effect model) }\end{array}$ & \multicolumn{2}{l}{$\begin{array}{l}\text { Confirmatory cohort } \\
\text { (linear model) }\end{array}$} \\
\hline Bistory of SARS-Cov-2 infection & Beta (SE) & Beta (SE) \\
\hline COV-No & & $7.31(0.21)$ & $<0.0001$ & $8.30(0.47)$ \\
\hline COV-Yes & $9.21(0.17)$ & $<0.0001$ & $9.20(0.72)$ \\
\hline Time since second dose of vaccine (months) & & $<0.0001$ \\
\hline Among COV-No subjects & $-0.35(0.02)$ & $<0.0001$ & $-0.49(0.07)$ \\
\hline Among COV-Yes subjects & $-0.29(0.02)$ & $<0.0001$ & $-0.31(0.12)$ \\
\hline Time since second dose of vaccine $x$ Covid-19 status & Interaction p-value $=0.051$ & Interaction p-value $=0.20$ \\
\hline
\end{tabular}


medRxiv preprint doi: https://doi.org/10.1101/2022.02.07.22270557; this version posted February 8, 2022. The copyright holder for this preprint (which was not certified by peer review) is the author/funder, who has granted medRxiv a license to display the preprint in It is made available under a CC-BY-NC 4.0 International license .

Figure 1: Number of days (D) between the $2^{\text {nd }}$ vaccination* and the 1 st and $2^{\text {nd }} \operatorname{IgG}(\mathrm{S})$ quantifications or the number of days between the $3^{\text {rd }}$ vaccination and the $3 \mathrm{rd} \operatorname{IgG}(\mathrm{S})$ quantification in the Main and Confirmatory cohorts

infection by SARS-COV-2

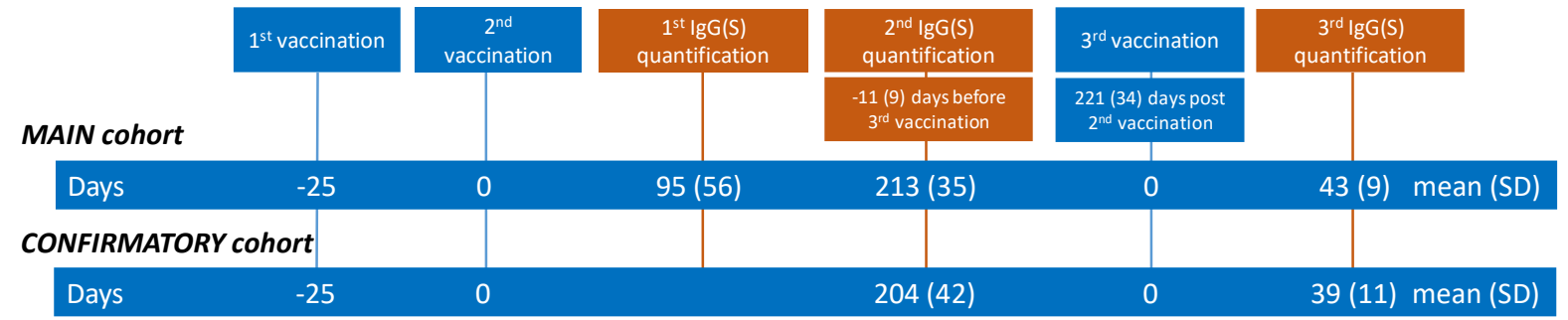

* For the 27 subjects who had SARS-CoV-2 infection a few days after the $2^{\text {nd }}$ vaccination (see legend figure 2), time to positive RT-PCR was taken into account in lieu of the $2^{\text {nd }}$ vaccination. 
medRxiv preprint doi: https://doi.org/10.1101/2022.02.07.22270557; this version posted February 8, 2022. The copyright holder for this preprint (which was not certified by peer review) is the author/funder, who has granted medRxiv a license to display the preprint in It is made available under a CC-BY-NC 4.0 International license .

Figure 2: Study flowchart
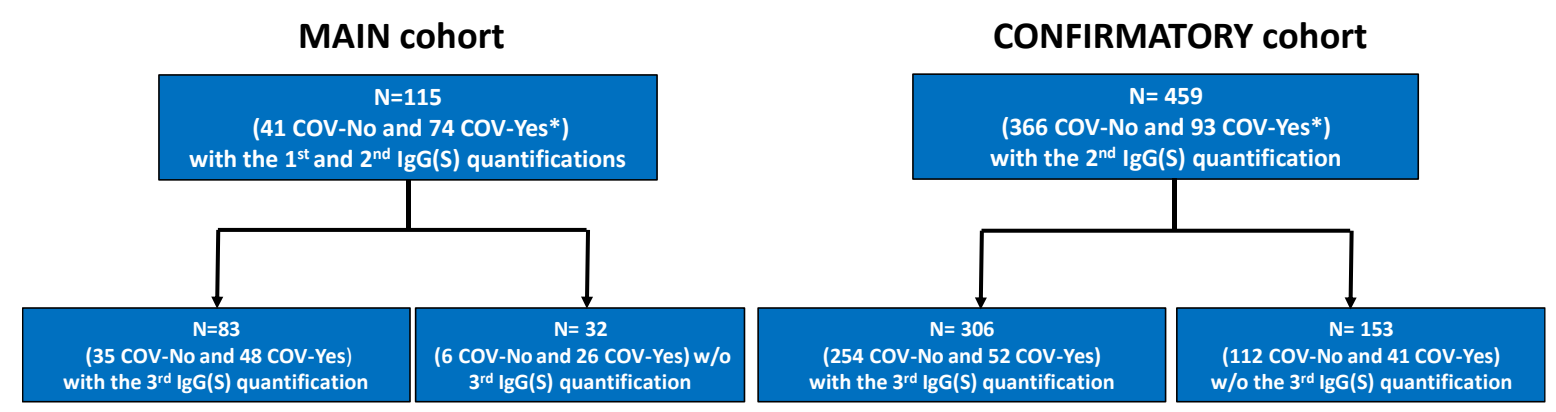

*Among COV-Yes subjects, 20 out of 74 in the Main cohort and 7 out of 93 in the

Confirmatory cohort hadSARS-CoV-2 infection a few days after the $2^{\text {nd }}$ vaccine dose

(February-March 2021). All other subjects had SARS-CoV-2 infection prior to the $1^{\text {st }}$ vaccine dose. 
medRxiv preprint doi: https://doi.org/10.1101/2022.02.07.22270557; this version posted February 8, 2022. The copyright holder for this preprint (which was not certified by peer review) is the author/funder, who has granted medRxiv a license to display the preprint in

perpetuity.
It is made available under a CC-BY-NC 4.0 International license .

Figure 3: Classification of the subjects in $4 \operatorname{IgG}(\mathrm{S})$ level categories $(\mathrm{BAU} / \mathrm{ml})$ during the $1^{\text {st }}$ (left), $2^{\text {nd }}$ (middle) and $3^{\text {rd }}$ (right) quantification according to history of SARS-CoV-2 contamination in the Main (upper) and the Confirmatory (lower) cohorts.
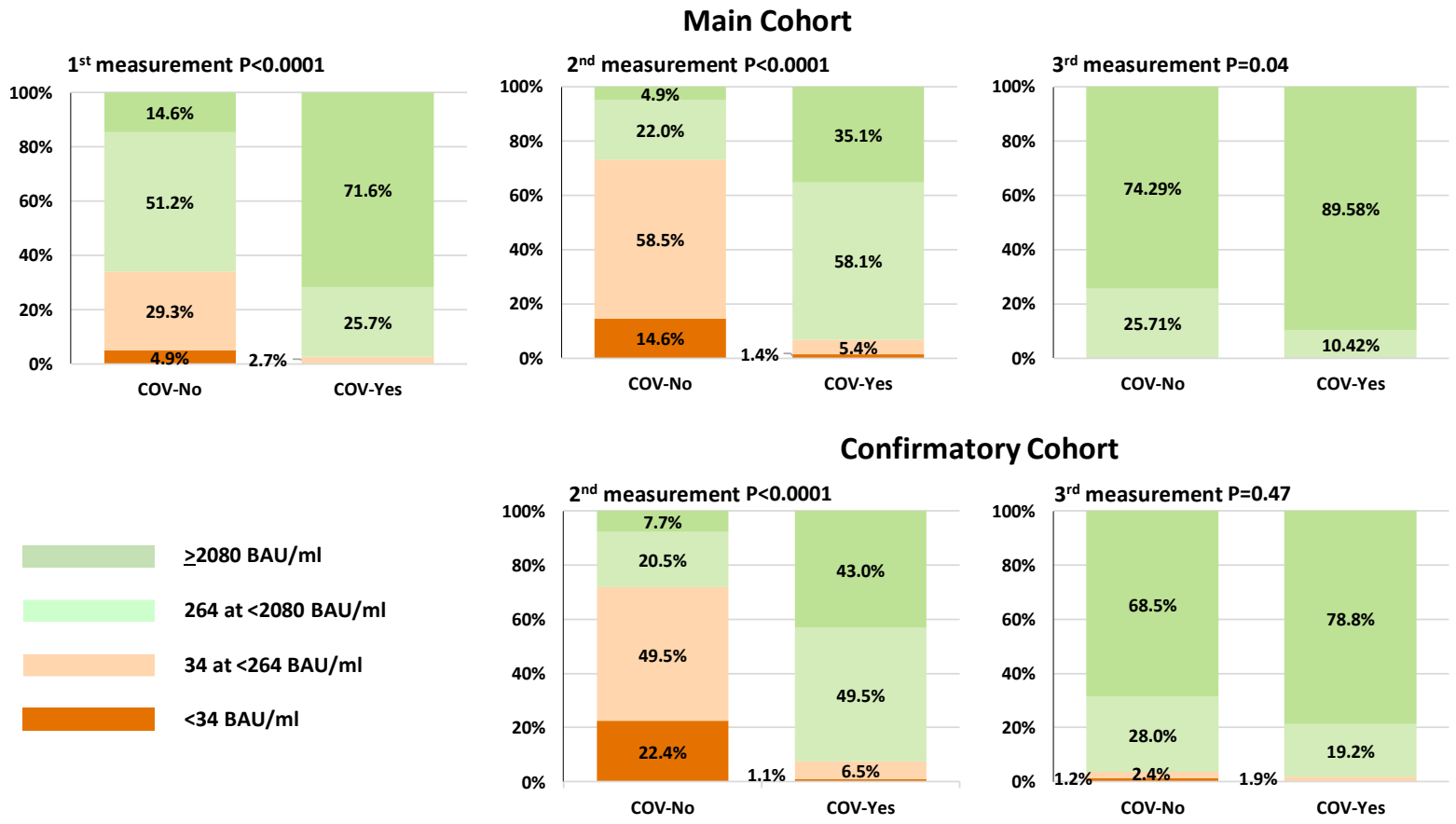
medRxiv preprint doi: https://doi.org/10.1101/2022.02.07.22270557; this version posted February 8, 2022. The copyright holder for this preprint (which was not certified by peer review) is the author/funder, who has granted medRxiv a license to display the preprint in It is made available under a CC-BY-NC 4.0 International license .

Figure 4: Distribution of $\operatorname{IgG}(\mathrm{S})$ levels according to time after the second dose of vaccine and COVID-19 status in the Main (left) and Confirmatory (right ) cohorts
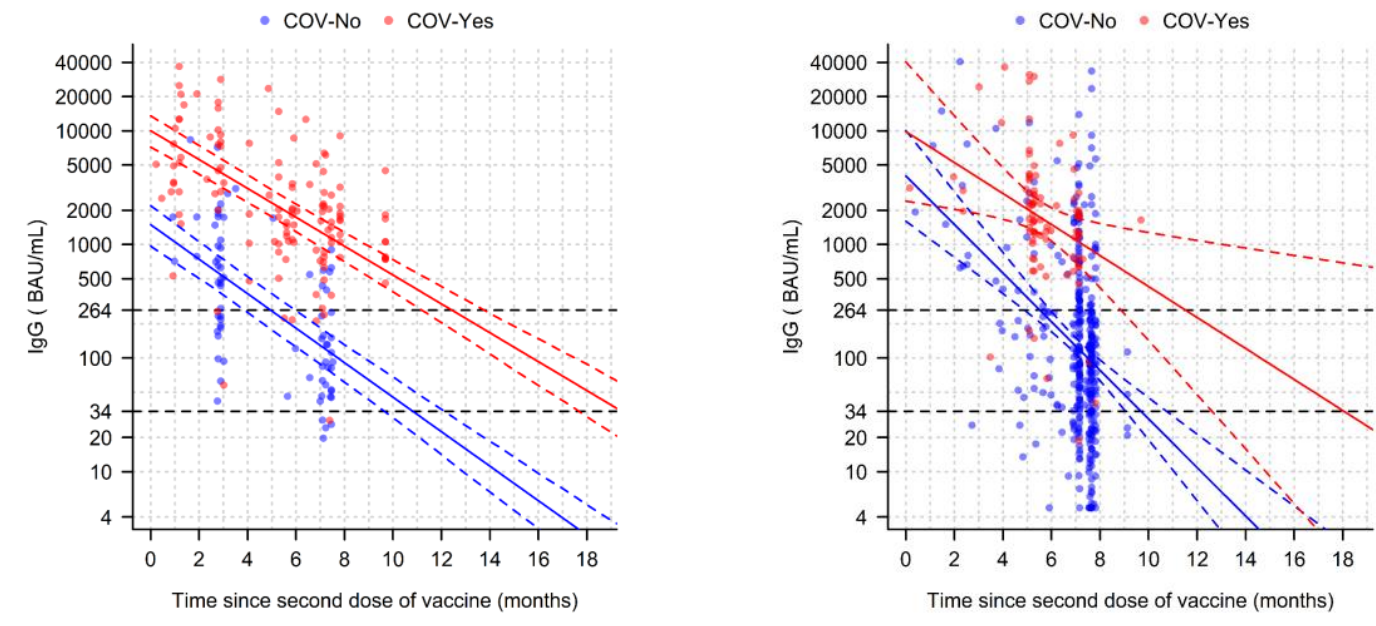

$\mathrm{IgG}$ is represented in logarithmic scale. Solid lines represent the predictions from the model and dotted lines the $95 \%$ confidence interval. The horizontal black dotted lines correspond to the $\operatorname{IgG}(\mathrm{S})$ titers of negative serology (34 BAU/ml) and of "robust" protection (264 BAU/ml) In the Main cohort, each individual is represented twice corresponding to the $1^{\text {st }}$ and the $2^{\text {nd }}$ $\operatorname{IgG}(\mathrm{S})$ quantifications in accordance with the linear mixed model described in the Methods section 